UDC $314.1(477)$

T. Vasyltsiv,

Doctor of Economic Sciences, Professor, Head of the Department, Dolishniy Institute

of Regional Research of the National Academy of Sciences of Ukraine, Lviv, Ukraine

ORCID ID: 0000-0002-2889-6924

R. Tesliuk,

$P h D$ in Geography, Senior Research Fellow, Dolishniy Institute of Regional Research

of the National Academy of Sciences of Ukraine, Lviv, Ukraine

ORCID ID: 0000-0003-4562-1663

DOI: $10.32702 / 2306-6806.2020 .4 .33$

\title{
DEMOGRAPHIC DIMENSION OF SUSTAINABLE DEVELOPMENT OF UKRAINE
}

Т. Г. Васильців,

А. е. н., професор, завідувач відділу, ДУ"Інститут регіональних досліджень

імені М. І. Долішнього НАН Украӥни", м. Аьвів, Украӥна

P. T. Теслюк,

к. геогр. н., Ст. н. С., АУ "Інститут регіональних, досліджень

імені М. І. Долішнього НАН Украӥни", м. Аьвів, Украӥна

\section{АЕМОГРАФІЧНИЙ ВИМІР СТААОГО РОЗВИТКУ УКРАЇНИ}

Sustainable development can be achieved with an optimal balance of demographic, economic and environmental development in a particular country or region. Population is an essential element of the social, economic and environmental spheres of any territory, so demographic sustainability should be seen as an indispensable condition for sustainable development in general. In the narrow sense, the demographic sustainability is interpreted as maintaining a constant population and characterized by indicators of population dynamics and changes in its age-old structure. In the broad sense, the demographic sustainability can be defined as an ability of a demographic sphere to main tain a stable population with optimal proportions between its age categories and a balanced social and economic structure of the society. It also means an ability to withstand external and in ternal factors of destabilizing the demographic situation and an ability to return to the previous balance state. The article defines the concept "demographic sustainability" and its relationship with the concept of sustainable development. The main factors of the regional dimension of demographic sustainability are outlined. The demographic sustainability of the region is considered as a result of the attractiveness of the region for education, work and human habitation. The main indicators of demographic sustainability and demographic dynamics in Ukraine are analyzed. The analysis of the age structure of the population showed a steady tendency of population aging and reduction of the absolute number of children. Along with this, the average life expectancy at birth is constantly increasing. The low total fertility rate confirms the lack of simple reproduction of the population and indicates a decrease in its population in the future.

The population pyramid for 2018 clearly indicates the inevitable further decline of the country's population and the growth of the proportion of older age groups in its structure. These processes are intensified by ongoing migratory movements, which are predominated by working-age population group.

Сталий розвиток може бутидосягнутий за оптимального співвідношення демографічного, економічного та екологічного розвитку в країні чи регіоні. Населення є важАивим елементом соціальної, економічної та екологічної сфер будь-якої території, тому демографічну стійкість СліА розглядати як неодміннУ умову сталого розвитку загалом. Увузькому розумінні демографічна стійкість трактується як підтримка постійної чисельності населення, що забезпечується його простим відтворенням. Уширокому розумінні демографічну стійкість можна визначити як здатність демографічної срери підтримувати стабільне населення з оптимальними пропорціями між його віковими категоріями та збалансованою соціально-економічною структурою суспільства. Показниками демографічної стійкості є кількісні та якісні параметри. На регіональному рівні істотний вплив маютьдодаткові фактори демографічної стійкості, пов'язані 3 життевими цикАами Аюдини: навчанням, роботою та проживанням загалом. Аналіз вікової структури населення показав стійку тенденцію старіння населення та зменшення абсолютної кількості дітей. Водночас середня тривалість життя при народженні постійно зростає. Низький загальний коефіцієнт народ- 
жуваності підтверджує відсутність простого відтворення населення та свідчить про скорочення чисельності населення в майбутньому. Тривалість таких змін у відтворенні населення відіграє кАючову роль, Стосовно України ці зміни, очевидно, мають довгостроковий ефект. Статево-вікова піраміда населення на 2018 рік чітко вказує на неминуче подальше зниження чисельності населення країни та зростання частки старших вікових груп у ї структурі. Ці процеси посилюються постійними міграційними рухами, в яких, фомінують групи працездатного віку. Тривалий процесдепопуляції викликає активізацію демографічних досліджень в Україні, які окреслюють нові виклики дАя економічного та соціального розвитку. Отже, дослідження компонентів демографічної стійкості демонструє СкАадність та різноманітність цієї концепції та ї визначну роль Удосягненні цілей сталого розвитку. У наш чаС це посилюється зростанням мобільності населення, формуванням нових форм зайнятості, в тому числі віртуальної. Крім того, тенденції останніх десятиліть визначають пріоритети, державної політики, спрямованої на запобігання депопуляції певних регіонів України та розробку ефективних заходів для забезпечення їхньої демографічної стійкості.

Key words: demograpbic economics, demograpbic sustainability, sustainable development, population structure, population pyramid, Ukraine.

Ключові слова: демографія, демографічна стійкість, стійкий розвиток, структура населення, статевовікова піраміданаселення, Україна.

\section{SETTING A TASK}

Considering the demographic component is a prerequisite for creating territorial development strategies. Such a strategy at the global level is the Sustainable Development Goals (SDGs), which were confirmed at the 2015 UN Sustainable Development Summit. Thus, the developed goals taking into account the national specifics have found their continuation at the national and even regional levels in some countries.

As population dynamics are inseparably linked to sustainable development, societies can adapt to demographic realities foreseeing future trends and incorporating this information into public policy and planning [1, p. 37]. The importance of obtaining reliable demographic information for planning development and assessing progress toward goals' achievement is emphasized by the United Nations Department of Economic and Social Affairs. The reliable and timely data on population size, population growth, population distribution and characteristics, as well as fertility, mortality and migration are necessary for creating global and national tasks for SDG implementation.

\section{ANALYSIS OF THE LATEST PUBLICATIONS}

The concept of a stable population was first introduced into the demographics by A. Lotka [2] as a separate case of the so-called "Malthusian populations". A. Lotka stated that a stable population can be seen as a limiting condition that a territorial community with a constant mortality and birth rate is aiming for. According to modern approaches (Z. Roca, M. Oliveira Roca) [3], the demographic sustainability of the region should be considered in two dimensions such as proper demographic (quantitative) and social-economic (qualitative) one. Some other dimensions of demographic sustainability are suggested by O. Roy [4]. He considers the demographic sustainability of the territory in structural and dynamic dimensions. Structural level reflects the population ratio of the territory and the degree of its economic impact (using the Zipf regularity). Some theoretical and methodological aspects of demographic sustainability have been considered by A.Nepytaliuk [5]. He has reflected essence and value of demographic sustainability at the terms of globalization. The theoretical approaches to the definition of the mentioned category as basis of endogenous economic grow th was systematized. O. Gladun and A. Romaniuk [6] investigated existing and forthcoming demographic tendencies in Ukraine. But demographic sustainability in the dimension of sustainable development is under-researched in relevant studies.

\section{PURPOSES OF THE RESEARCH}

The aim of this article is to analyze the concept "demographic sustainability" and its relationship with the concept sustainable development as well as to outline the main indicators of demographic sustainability in Ukraine.

\section{RESULTS OF THE RESEARCH}

Theoretical aspects of demographic sustainability.

According to the peculiarities of demographic dynamics (population growth or decline), countries can be conventionally divided into 3 groups. Most developed countries are at the stage of the second demographic transition that is characterized by low mortality, low birth rate and, consequently, low population growth rates (USA, UK, Germany, France, Japan, Australia). Instead, the global population growth is driven mainly by high birth rates in countries of the second group (mostly in Africa and South Asia). The third group is formed by the countries with a steady tendency of population decline (countries of Eastern and Central-Eastern Europe, including Ukraine). At the same time, there are regional differences in the demographic processes in each country.

Differences in the course of demographic processes at the national and regional levels cause the development of fundamentally different directions of demographic social and economic policies in different countries and regions. However, in all cases, it is necessary to proceed from the point of the optimal correlation between the demographic, economic and environmental spheres of a particular country or region. The key elements of this relationship are the concept of balance and sustainability of the mentioned spheres. The population is an essential element in the functioning of social, economic and environmental spheres of any territory, and demographic sustainability should be considered as an indispensable condition for sustainable development in general. On the other hand, any measures are aimed at improving the life quality of population and the environment as a whole. Therefore, one of the main criteria for assessing the development sustainability of national and regional communities should be indicators of demographic sustainability, which in this case should be considered with reference to the specific territory of population, namely country, region or settlement.

On this basis, it is important to provide an understanding of demographic sustainability within the concept of sustainable development. The concept of sustainable development involves the formation of a long-term balance of three subsystems that are environmental, economic and 
Table 1. The main indicators of demographic sustainability in the region

\begin{tabular}{|l|l|}
\hline \multicolumn{1}{|c|}{ Demo-reproductive dimension } & \multicolumn{1}{c|}{ Social and economic dimension } \\
\hline population size & population density \\
\hline age structure of the population & urban and rural population \\
\hline fertility, mortality and birth rate & $\begin{array}{l}\text { rate of the population with higher } \\
\text { education }\end{array}$ \\
\hline $\begin{array}{l}\text { number of immigrants, emigrants } \\
\text { and migration balance }\end{array}$ & $\begin{array}{l}\text { rates of male and female active population } \\
\text { in agriculture, industry and services }\end{array}$ \\
\hline total fertility rate & rate of students \\
\hline net fertility rate & unemployment rate \\
\hline average life expectancy & $\begin{array}{l}\text { rates of employers, employees, self- } \\
\text { employed and unpaid family workers in } \\
\text { the total active population }\end{array}$ \\
\hline infant mortality rate & $\begin{array}{l}\text { rate of highly skilled, skilled industrial, } \\
\text { agricultural and unskilled workers in the } \\
\text { total economically active population }\end{array}$ \\
\hline
\end{tabular}

social ones. Accordingly, demographic sustainability is one component of the social subsystem.

The demographic sustainability is interpreted as maintaining a constant population, which is ensured by its simple reproduction in a narrow sense. In this sense, demographic sustainability is characterized by indicators of population dynamics and changes in its age-old structure (in particular, the relation between the population shares in working and post-working age). In other words, we are talking about the so-called "stationary population". However, it should be noted that not only the size of the population is important, but also its distribution by age, gender, education and level of involvement in the national economy, etc.

In the broad sense, the demographic sustainability can be defined as an ability of a demographic sphere to maintain a stable population with optimal proportions between its age categories and a balanced social and economic structure of the society. At the same time, sustainability also means an ability to withstand external and internal factors of destabilizing the demographic situation and an ability to return to the previous balance state.

The demographic sustainability of the region should be considered in two dimensions such as proper demographic (quantitative) and social and economic (qualitative) one [3, p. 22]. From the point of quantitative (demo-reproductive) parameters, the territory is considered to be demographic sustainable if there is an optimal ratio between the population size (natural and mechanical growth) and the growth rates of age groups of population. In addition to the natural and mechanical movement of the population and its age-old structure, the indicators of demographic sustainability are also the marital and family structure of the population, the life expectancy, the demographic dependency, various relationships between the population of working age and retirement age (demographic load, potential support ratio etc.).

From a qualitative (social and economic) dimension, a region is considered demographically sustainable if it has a balanced social and economic structure of the population. In addition to the characteristics of economic activity, professional structure and education, the social and economic indicators of demographic sustainability are national and religious complement, social structure (population stratification), regional structure, population distribution by sources of livelihoods, and Gini coefficient etc.

It can be stated that demographic sustainability is a state of the demographic sphere of the region, which ensures the continuous restoration of quantitative and qualitative demographic structures in the corresponding historical and social and economic conditions. Assessment of demographic sustainability in general or its individual elements is largely driven by the goals of the demographic social and economic development of a country or region. The condition for the sustainable development of the territory is the stabilization or moderate population growth. Depending on the current trends in the demographic development of the country and its regions, as well as the principles of demographic policy of the country, the achievement of a stable population may occur with help of small natural or mechanical population growth.

A. Roy identified the factors of demographic sustainability of the region. Regions will be considered to be demographically stable where there are no significant disparities between the ranks of the largest settlements in terms of population and economic development. In other words, it is about an equal distribution of its demographic social and economic potential across the region $[4$, p. $39-$ 40].

Dynamic dimension is formed as territorial communities are evolving and it manifests itself as an environment for realizing the needs and interests of residents in a particular region, especially getting education, finding a job, buying or renting an accommodation, and providing a comfortable life after retirement [4, p. 42].

Additional demographic sustainability factors are beginning to be applied at the region level. The key ones are:

- the presence of a large city and its administrative status in the region (metropolitan functions);

- the developed system of higher and secondary education (attractiveness for young people, as well as for potential residents of the region);

- the economic potential of the region (expansion of the labour market);

- the rates of construction of new housing (availability of effective demand and availability of mortgage lending);

- the well-established infrastructure (business conditions, access to services);

- the scientific nature of certain areas of enterprises' activity (development of specialized small enterprises, or individual entrepreneur).

In addition to the objective determinants of the demographic sustainability of the region, subjective ones are important as they are related to specific decisions by people in certain social, economic and ecological conditions.

From this point of view, the demographic sustainability of a particular region can be seen as a result of the region's attractiveness for three important factors such as learning, work and living habits. Accordingly, it can be distinguished three so-called branches of the human life path, which determine person's decision regarding the choice of residence [4, p. 43].

1. Educational branch is related to the need to choose a full and demanded education. There are enough educational institutions in the region that can hold their own youth and attract students from other regions (countries).

2. Labour branch is the level of salary in comparison with neighbouring regions (countries) that determines the level, direction and type of migration of able-bodied population.

3. Housing branch is connected with the choice of residence place. The availability of affordable tools for buying or renting accommodation can help to keep mostly younger categories of able-bodied population.

Demographic dynamics and demographic sustainability in Ukraine.

For Ukraine and its regions, such factors are the negative tendencies of the natural movement of the population, the migration outflow, the worsening of the life quality, the economic crisis, the military and political conflict, etc. Ukraine is the 15 th in terms of population decline over the last decade (4.5\%) [1, p.15]. Furthermore, UN experts predict further decline in next 30 years by almost $20 \%$ ( 5 th place in the world).

As of January 1, 2019 the permanent population of Ukraine accounted for 42153.2 thousand people (disregarding the occupied Crimean peninsula). In general, during the last 5 years $(2014-2018)$ population of the country has 
Table 2. Indicators of demographic sustainability in Ukraine

\begin{tabular}{|c|c|c|c|c|c|c|c|c|c|}
\hline \multirow{2}{*}{\multicolumn{3}{|c|}{ Indicators }} & \multicolumn{7}{|c|}{ Years } \\
\hline & & & 1989 & 1995 & 2000 & 2005 & 2010 & $2015^{1}$ & $\mathbf{2 0 1 8}^{2}$ \\
\hline \multicolumn{3}{|c|}{ Population (total), thousands } & 51452.0 & 51300.4 & 49115.0 & 47100.5 & 45782.6 & 42759.7 & 42216.8 \\
\hline \multirow{3}{*}{$\begin{array}{l}\text { Age } \\
\text { structure }\end{array}$} & \multicolumn{2}{|c|}{ population aged $0-14, \%$} & 21.6 & 20.5 & 17.9 & 14.8 & 14.2 & 15.1 & 15.5 \\
\hline & \multicolumn{2}{|c|}{ population aged $15-64, \%$} & 66.7 & 65.9 & 68.2 & 69.2 & 70.2 & 69.3 & 68.0 \\
\hline & \multicolumn{2}{|c|}{ population aged $65+, \%$} & 11.7 & 13.6 & 13.9 & 16 & 15.6 & 15.6 & 16.5 \\
\hline \multicolumn{3}{|c|}{ Total fertility rate (per one female) } & 1.94 & 1.40 & 1.12 & 1.21 & 1.45 & 1.51 & 1.37 \\
\hline \multicolumn{3}{|c|}{ Population $0-14$ per 100 people aged $65+$} & 184 & 151 & 129 & 93 & 90 & 97 & 94 \\
\hline \multirow{2}{*}{\multicolumn{2}{|c|}{$\begin{array}{l}\text { Demographic dependency on } \\
\text { population aged } 15-64 \text { (per } \\
1000 \text { people) }\end{array}$}} & total & 499 & 517 & 465 & 445 & 425 & 443 & 470 \\
\hline & & $\begin{array}{l}\text { population } \\
\text { aged } 65+\end{array}$ & 176 & 206 & 203 & 230 & 223 & 225 & 243 \\
\hline \multicolumn{3}{|c|}{ Potential support ratio } & 5.7 & 4.9 & 4.9 & 4.3 & 4.5 & 4.4 & 4.1 \\
\hline \multicolumn{3}{|c|}{ Average age, years } & 36.5 & 37.2 & 38.4 & 39.5 & 40.2 & 40.7 & 41.3 \\
\hline \multicolumn{3}{|c|}{$\begin{array}{l}\text { Sex ratio of the population aged } 65+ \\
\text { (females per } 100 \text { males) }\end{array}$} & 241 & 215 & 204 & 194 & 200 & 201 & 198 \\
\hline \multirow{2}{*}{\multicolumn{2}{|c|}{$\begin{array}{l}\text { Average life expectancy at } \\
\text { birth, years }\end{array}$}} & male & 65.6 & 61.2 & 62.1 & 62.2 & 65.3 & 66.4 & 67.0 \\
\hline & & female & 74.8 & 72.5 & 73.5 & 74.0 & 75.5 & 76.3 & 76.8 \\
\hline
\end{tabular}

${ }^{1}$ Here and throughout the article all the demographic data presented in the text (unless mentioned otherwise) is based on the official website of the State Statistics Service of Ukraine and the government portal "Population of Ukraine" maintained by the State Statistics Service of Ukraine. All of the national level data after 2014 is presented without the input from temporarily occupied Autonomous Republic of Crimea, same concerns all of calculated indicators.

${ }^{2}$ Excluding data from Autonomous Republic of Crimea due to unavailability.

${ }^{3}$ Excluding data from Autonomous Republic of Crimea due to unavailability.

Source: developed by the second author based on data from the "Population of Ukraine" portal (State Statistics Service of Ukraine).

decreased by 919.2 thousand people (or $2.0 \%$ ), yet altogether with the population lost to Russia the number increases to 3.27 million (or $7.2 \%$ ). Analysis of this indicator since 1989 indicates its rapid decline up to year 2010, and the slowdown in the rates of decline during the $2011-2014$. However, the annexation of the Crimea and military occupation of the eastern regions of the country have drastically influenced the decline, weakened the conditions for natural reproduction of the population and provoked migratory processed from eastern regions to the rest of the country and abroad.

One of the main indicators of demographic sustainability is the population age structure. Over the last 30 years there have been significant changes in this structure. First, reduction in the number of children has occurred - from 11.1 million in 1989 to 6.5 million in 2018. Same trend is present for the working-age population decrease from 34.3 million to 28.7 million respectively. The absolute number of people aged 65 and older has increased from 6 to 7 million, and in 2007 the number of this age group has reached its maximum of 7.6 million. This indicates that ageing in Ukraine over the analysed period is resulting primarily from the "bottom-up" type, being the reflection of gradual (yet relatively swift) reduction in the number of children (mainly due to the decrease in the birth rate). However, the positive dynamics of the average life expectancy at birth (Table 2) against the increase in elderly population groups' indicate the so-called "topbottom" ageing, which occurs from decline of mortality of the elderly with simultaneous relatively slow increase in the number of children.

Another indicator of demographic sustainability is the overall fertility rate, calculated as the average number of children per woman. Since 1989, this indicator has begun to sharply decline - from 1.94 in 1989 to as low as 1.12 in 2000 (Table 2). In the following years there was a gradual increase in the total fertility rate, however, the fluctuation of this indicator within the range of $1.21-1.51$ points to an aforementioned further decrease in the proportion of children in relation to other age groups ${ }^{4}$. In general, over the 30 years, the number of children per 100 population aged $65+$ has decreased almost twofold - from 184 to 94 .

Significant differences in demographic sustainability exist between urban and rural areas. Depopulation of Ukrainian rural areas in most regions began in the 80 's, as

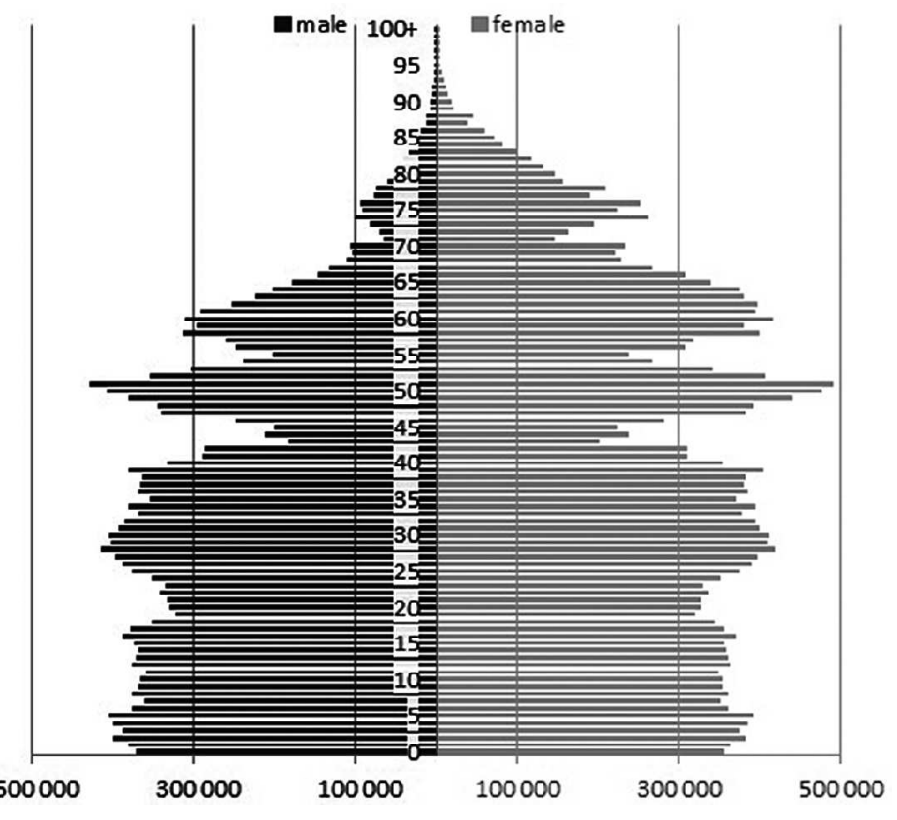

Figure 1. Population pyramids for Ukraine in 1989

Source: developed by the second author based on data from he "Population of Ukraine" portal

(State Statistics Service of Ukraine).

there was a steady outflow of rural youth to the urban areas, gradually resulting in increasing differences in the proportion of elderly people in cities and villages, which for a long time was quite high $-7.1-7.3 \%$ during $1989-$ 1998. Later on a steady approximation of this indicator occurred with its simultaneous growth for both rural and urban population. As the rates of such growth in cities were higher, by 2018 the difference between the population shares at the age of $65+$ was only $1.3 \%$. The population aged $65+$ in cities and villages of Ukraine has increased significantly over the past 30 years - by $6.7 \%$ and $0.9 \%$ respectively.

Changes in the age structure of the Ukrainian population can be well illustrated by the pyramids of the age sex. Figure 1 shows that by 1989 there was a stable birth

${ }^{4}$ In order to maintain basic population reproduction the total fertility rate should equal $2.0-2.2$. 


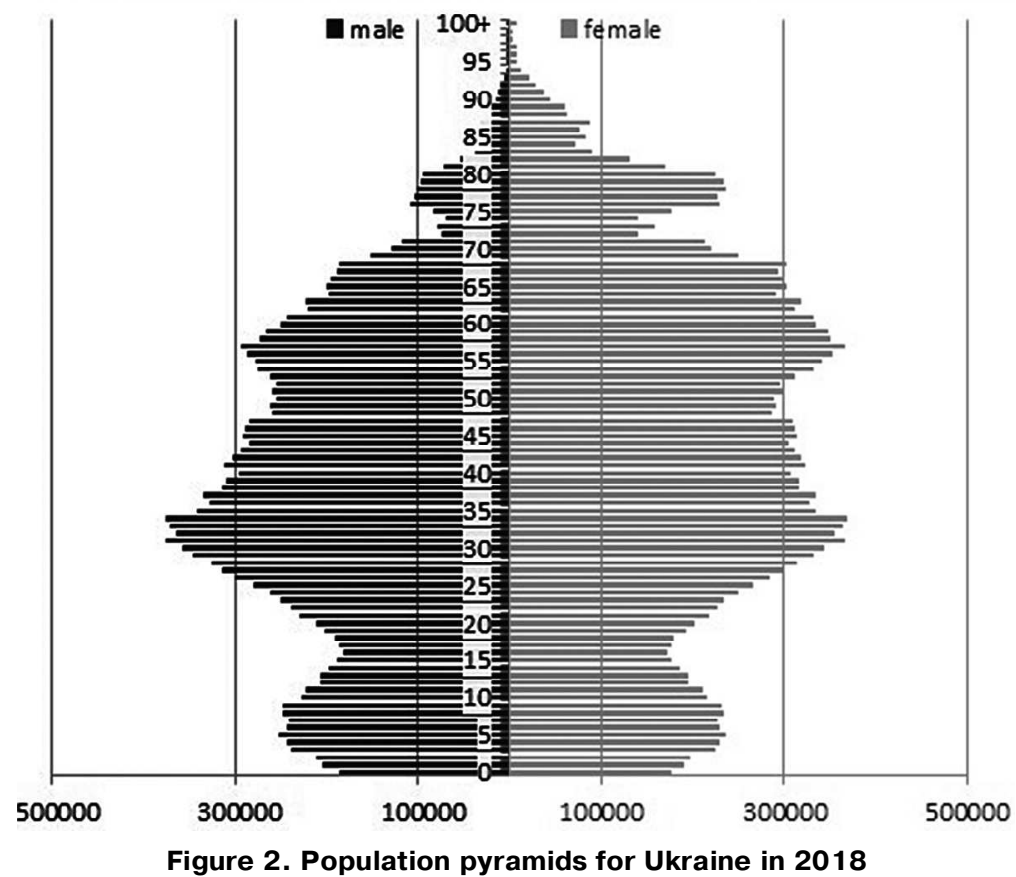

Source: developed by the second author based on data from the "Population of Ukraine" portal (State Statistics Service of Ukraine).

rate. Thereafter, the decline in birth rate at the beginning of the analysed period is already reflected in the number of working age population, as it is being supplemented by less young people, while the elderly group are gaining numbers. The population pyramid in 2018 (fig. 2) clearly indicates the inevitable further reduction of nation's population and the growth of the $65+$ age groups in its structure. Large gender imbalances in elderly age groups are also noticeable despite the decline in the sex ratio of the population aged $65+$ (number of females per 100 males), the female population in this group is in total twice as high.

Another indicator of demographic sustainability is the average life expectancy at birth. This indicator has been dropping in case of males from 65.6 years in 1989 to 62.1 years in 2000 , yet later regained the primary level and even exceeded it in the 2018 with the value of 67.0 years. Similar with the female indicator observed at the level of 74.8 years in 1989 and later characterized by a softer decline followed by a quicker upward dynamic from mid-90ies reaching 76.8 years in 2018. Yet breakdown of this indicator into urban and rural population shows wide margins between these types of residents, which have been growing in the past 13 years in case of females and for 17 years in case of males. As of 2017 rural males' average life expectancy equaled 65.5 years and was 2.35 years shorter from urban residents, while in case of females in rural areas the same indicator equaled 76 years being 1.13 years shorter from urban. Breakdown of this indicator into urban and rural population shows wide margins between these types of residents, which have been growing in the past 13 years in case of females and for 17 years in case of males. As of 2017 rural males' average life expectancy equaled 65.5 years and was 2.35 years shorter from urban residents, while in case of females in rural areas the same indicator equaled 76 years being 1.13 years shorter from urban.

\section{CONCLUSIONS}

Demographic policy is an important component of the UN Sustainable Development Goals. Countries in the world have distinctive demographic dynamics (population growth or decline), but in all cases, one must start from a sustainable reproduction of the demographic, economic and environmental spheres of a particular country or region.

In the narrow sense, demographic sustainability is interpreted as maintaining a constant population, which is ensured by its simple reproduction (as a separate case of the so-called "Malthusian population"). In a broad sense, demographic sustainability can be defined as the ability of a demographic to maintain a stable population with optimal proportions between its age categories and a balanced socioeconomic structure of society. At the same time, "sustainability" also means the ability to withstand external and internal factors destabilizing the demographic situation and the ability to return to the previous equilibrium. Indicators of demographic sustainability are quantitative (natural and mechanical population movement, age structure, marital and family structure of the population, life expectancy, demographic load, different relationships between the population of working age, working age and retirement age) and qualitative parameters (socio-economic structure and religious composition, social structure, regional structure, distribution of population by livelihoods, Gini coefficient). Additional demographic sustainability factors related to human life cycles, such as study, work and living, are taking place at the regional level.

Analysis of demographic processes in Ukraine during the past 30 years indicates a steady trend towards ageing, which from the demographic point of view is the process in which the share of elderly people in the total population is increasing. Duration of such changes in reproduction of population is playing a key role, and in case of Ukraine these changes are evidently having a long-term effect. The population pyramid for 2018 clearly indicates the inevitable further decline of the country's population and the growth of the proportion of older age groups in its structure. These processes are intensified by ongoing migratory movements (mainly from rural areas to cities or from rural and urban areas abroad), which are predominated by working-age population group.

The long going process of depopulation is causing the intensification of demographic researches in Ukraine, which allow outlining of new challenges for economic and social development. Permanent natural population began its swift decline at the nineties of the twentieth century and was a reflection of two steady trends: a sharp drop in birth rate and a relatively slower increase in mortality rate, caused by the population's age structure (high share of people aged 65 and over). From the beginning of the XX century and until now depopulation is being intensified by strong migration processes, which reflect different vectors and 
characteristics. Due to such development of the demographic situation in Ukraine over the past three decades, the age structure of the nation's population has become substantially deformed.

Thus, research into the components of demographic sustainability demonstrates the complexity and diversity of this concept and its prominent role in achieving the Sustainable Development Goals. Nowadays, this is enhanced by the increase in the mobility of the population, the formation of new forms of employment, including virtual one. In addition, the trends of the last decades make the priority to prevent depopulation of certain regions of Ukraine and to develop effective measures to ensure their demographic sustainability.

\section{$\Lambda$ ітература:}

1. World Population Prospects 2019. Highlights (2019), Department of Economic and Social Affairs, Population Division, United Nations, New York, 46 p., available at: https://population.un.org/wpp/Publications/Files/ WPP2019 Highlights.pdf

2. United Nations (1968), "The concept of a stable population - application to the study of populations of countries with incomplete demographic statistics" (United Nations Publications, Sales No. E.65.XIII.3). Lotka, Alfred J. Chapter I. The concept of a stable population, available at: https://www.un.org/en/development/desa/population/ publications/pdf/manuals/model/stablepopulation/ chap1.pdf

3. Roca,Z. and Oliveira Roca, M. (2014), "Demographic sustainability and development in Portugal", Acta geographica Bosnia et Hercegovina, No2, pp. 21-28, available at: https://www.geoubih.ba/publications/Acta2/ Article-Z.\%20Roka,Maria\%20de\%20Nazar\% C $3 \%-$ A9\%20Oliveira\%20Roca.pdf

4. Рой О.М. Аемографическая устойчивость территории: методология оценки / О.М. Рой // Аемографическая и семейная политика в контексте целей устойчивого развития: сборник статей IX Уральского демографического форума: в 2-х томах. - Том I. - Екатеринбург: Институт экономики УрО РАН, 2018. - С. 38-51. - Режим доступу: http:// elar.urfu.ru/bitstream/10995/ 68266/1/978-5-94646-613-4_2018-1-03.pdf

5. Nepytaliuk A. (2018), "Demographic sustainability and economic grow th: theory and methodology", Herald of Kyiv national university of trade and economics, vol. 6 , pp. 52-66, available at: http://nbuv.gov.ua/UJRN/ Vknteu $2018 \quad 6 \quad 1$

6. Романюк А.І., Гладун О.М.Аемографічні тенденції в Україні: минуле, сьогодення і майбутнє / A.I. Романюк, О.М. Гладун // Аемографія та соціальна економіка. - № 3. - 2015. - С. 21-42.

7. Населення України: портал / Аержавна служба статистики України. - Режим доступу: http://database.ukrcensus.gov.ua/MULT/Dialog/statfile_c.asp

\section{References:}

1. World Population Prospects 2019. Highlights (2019), Department of Economic and Social Affairs, Population Division, United Nations, New York, 46 p., available at: https://population.un.org/wpp/Publications/Files/ WPP2019 Highlights.pdf (Accessed: 22.03.2020).

2. United Nations (1968), "The concept of a stable population - application to the study of populations of countries with incomplete demographic statistics" (United Nations Publications, Sales No. E.65.XIII.3). Lotka, Alfred J. Chapter I. The concept of a stable population, available at: https://www.un.org/en/development/desa/population/ publications/pdf/manuals/model/stablepopulation/ chap1.pdf (Accessed: 22.03.2020).

3. Roca, Z. and Oliveira Roca, M. (2014), "Demographic sustainability and development in Portugal", Acta geographica Bosnia et Hercegovina, No2, pp. 21-28, available at: https://www.geoubih.ba/ publications/Acta2/
Article-Z.\%20Roka,Maria \%20de\%20Nazar\%C3\%A9\%20Oliveira\%20Roca.pdf (Accessed: 22.03.2020).

4. Roy, O. M. (2018), "Demographic sustainability of the territory: evaluation methodology", IX Uralskiy demograficheskiy forum "Demograficheskaya i semeynaya politika kontekste tseley ustoychivogo razvitiya" [IX Ural Demographic Forum "Demographic and family policy in the context of sustainable development goals"], Mezhdunarodnaya nauchnaya konferentsiya [International Scientific Conference], vol. I, pp. 38-51. Institute of Economics, Ural Branch of RAS, Yekaterinburg, Russia, available at: http://elar.urfu.ru/bitstream/10995/68266/1/ 978-5-94646-613-4 2018-1-03.pdf (Accessed: 22.03.2020).

5. Nepytaliuk, A. (2018), "Demographic sustainability and economic growth: theory and methodology", Herald of Kyiv national university of trade and economics, vol. 6 , pp. 52-66, available at: http://nbuv.gov.ua/UJRN/ Vknteu 2018 6 1 (Accessed: 22.03.2020).

6. Romaniū, A.I. and Gladun, O. M. (2015), "Demographic Trends in Ukraine: past, present and future", Demografiia ta socialna ekonomika, vol. 3, pp. $21-42$.

7. Population of Ukraine: portal (2018), State Statistics Service of Ukraine, available at: http://database.ukrcensus.gov.ua/MULT/Dialog/statfile_c.asp (Accessed: 22.03.2020).

Стаття надійшла до редакиї 23.03.2020 p.

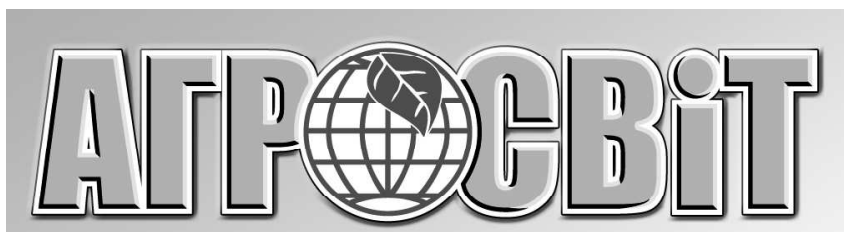

wWw. agrosvit. info

Передплатний індекс: 23847

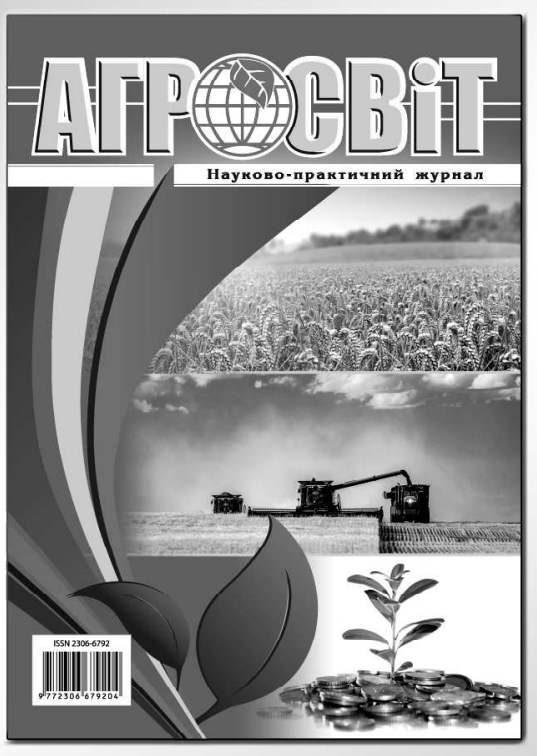

Виходить 24 рази на рік

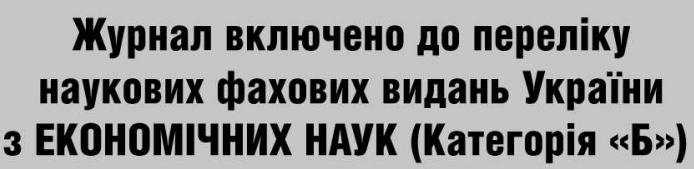

Спеціальності - 051, 071, 072, 073, 075, 076, 292 